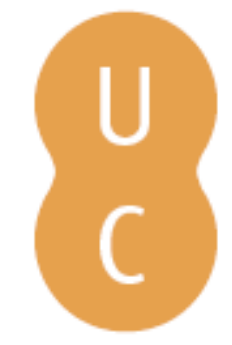

\title{
pommalina
}

\section{Slope behaviour in highways: a decade of deterioration in metamorphic rocks with volcano-sedimentary origin along the IP4 (NE Portugal)}

\author{
Autor(es): $\quad$ Sá, A. A.; Ferreira, M. Portugal; Pires, C. C. \\ Publicado por: Imprensa da Universidade de Coimbra \\ URL \\ persistente: URI:http://hdl.handle.net/10316.2/39160 \\ DOI: $\quad$ DOI:http://dx.doi.org/10.14195/978-989-26-0321-6 \\ Accessed : $\quad$ 26-Apr-2023 14:24:19
}

A navegação consulta e descarregamento dos títulos inseridos nas Bibliotecas Digitais UC Digitalis, UC Pombalina e UC Impactum, pressupõem a aceitação plena e sem reservas dos Termos e Condições de Uso destas Bibliotecas Digitais, disponíveis em https://digitalis.uc.pt/pt-pt/termos.

Conforme exposto nos referidos Termos e Condições de Uso, o descarregamento de títulos de acesso restrito requer uma licença válida de autorização devendo o utilizador aceder ao(s) documento(s) a partir de um endereço de IP da instituição detentora da supramencionada licença.

Ao utilizador é apenas permitido o descarregamento para uso pessoal, pelo que o emprego do(s) título(s) descarregado(s) para outro fim, designadamente comercial, carece de autorização do respetivo autor ou editor da obra.

Na medida em que todas as obras da UC Digitalis se encontram protegidas pelo Código do Direito de Autor e Direitos Conexos e demais legislação aplicável, toda a cópia, parcial ou total, deste documento, nos casos em que é legalmente admitida, deverá conter ou fazer-se acompanhar por este aviso.

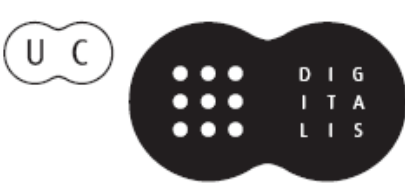


MARTIM PORTUGAL V. FERREIRA

Coordenação

\section{A Geologia de Engenharia e os Recursos Geológicos} VOL. 1 - GEOLOGIA DE ENGENHARIA

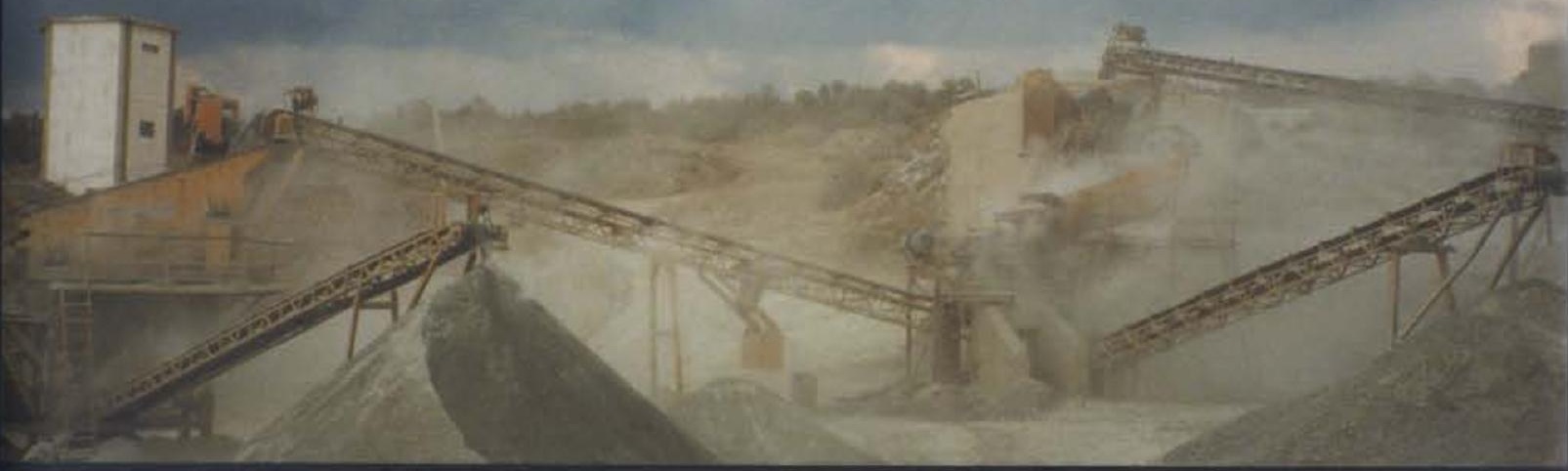




\title{
SLOPE BEHAVIOUR IN HIGHWAYS: A DECADE OF DETERIORATION IN METAMORPHIC ROCKS WITH VOLCANO-SEDIMENTARY ORIGIN ALONG THE IP4 (NE PORTUGAL)
}

\author{
A. A. $\mathbf{S A}^{\prime}$ ', M. Portugal Ferreira ${ }^{2}$ e C. C. Pires ${ }^{1}$
}

PALAVRAS-CHAVE: taludes artificiais, estabilidade, deterioração, factores, unidades vulcano-sedimentares, detritos.

KEY WORDS: artificial slopes, stability, deterioration, factors, volcano-sedimentary units, debris.

\section{ABSTRACT}

A decade after the opening of the IP4 (principal itinerary Porto-Bragança) between Mirandela and Macedo de Cavaleiros, it is stimulating and possible to evaluate the amount of rock material removed from the excavated slopes, in the intermediate to low grade metamorphic Lower Palaeozoic rock units along a segment of twenty kilometres. These units comprehend the quartzphyllites, greenstones and greenschists, metarhyolites and metamorphic tuffs and tuffites of a broad synform.

The deterioration types, the volume of the debris, the major dimension of the rock fragments and the length of deteriorated sites are evaluated against the rock types, the density, orientation and opening of the descontinuities, degree of weathering, geometry of the slope and the prevalent foliation. The deterioration susceptibilities $(\mathrm{RDA}+\mathrm{e})$ found for the whole length of these highway slopes, range from 54 to 99 (the full interval ranges from 6 to 160). It can be tested against an attempted index of actual deterioration of the slopes (ADS) which is found to range between 8 and

${ }^{1}$ Departamento de Geologia - UTAD - Ap. 1013, 5001-911 Vila Real.

${ }^{2}$ Centro de Geociências - Dep. Ciências da Terra, FCTUC, 3000-272 Coimbra. 
18 (the full interval is 4 to 20). It has been found that these two indices show a positive correlation expressed as $\mathrm{ADS}=0,26 \mathrm{RDA}-5,64$ for an $\mathrm{R}^{2}=0,56$. If it were used the $(\mathrm{RDA}+\mathrm{e})$, the correlation would be worse. The most deteriorated segment is located in the thermally recrystalized and preferentially fractured volcano-sedimentary units that crop out in the western limb of the Romeu antiform.

\section{Resumo: \\ O comportamento de taludes de rodovias: uma década de deterioração em ro- chas metamórficas de origem vulcano-sedimentar ao longo do IP4 (NE Portugal)}

Uma década após a abertura do troço do IP4 entre Mirandela e Macedo de Cavaleiros (itinerário principal Porto-Bragança) é estimulante avaliar a quantidade de material rochoso caído dos taludes escavados em rochas metamórficas do Paleozóico Inferior, numa extensão de vinte quilómetros. Estas unidades compreendem quartzofilitos, xistos verdes, metarriolitos, tufos metamórfico e tufitos de uma sinforma aberta.

Os tipos de deterioração, o volume de detritos, a dimensão dos maiores fragmentos rochosos e a extensão dos locais deteriorados foram avaliados tendo em atenção o tipo de rochas, a densidade, a orientação e abertura das descontinuidades, o grau de alteração, a geometria do talude e a foliação predominante. As susceptibilidades de deterioração $(\mathrm{RDA}+\mathrm{e})$ encontradas para a extensão total destes taludes situam-se no intervalo 54 a 99 (o intervalo total varia entre 6 e 160); foram testadas contra um índice de deterioração real dos taludes, aqui proposto como ADS, o qual varia entre 8 e 18 (o intervalo total vai de 4 a 20). Os índices RDA apresentam uma correlação positiva que se expressa como $\mathrm{ADS}=0,26 \mathrm{RDA}$ - 5,64 para um $\mathrm{R}^{2}=0,56$. Se fosse usado o $(\mathrm{RDA}+\mathrm{e})$ a correlação seria mais pobre. $\mathrm{O}$ segmento mais deteriorado encontra-se nas unidades vulcano-sedimentares, com recristalização de contacto e preferencialmente fracturadas, do flanco oeste da antiforma do Romeu.

\section{INTRODUCTION}

The intrinsic qualities of the rock slope foundations and the type and classes of instabilities as well as the resulting collapsed rock materials thereon incident are closely related (PERRY \& O'REILLY, 1990; GONZÁLEZ DEL VALLEJO et al., 2002).

Consequent to the surveying of the machined slopes, along a $20 \mathrm{~km}$ segment of the highway IP4 (Porto - Bragança), carried by SÁ (1999), it is here shown some of the deterioration phenomena that have been found on the different units of a lithostratigraphic sequence, dated from the Lower Palaeozoic, which is 
composed of phyllites-micaschists and their overlaying para-ophiolitic suite - greenstones, greenschists, metarhyolites, graded metavolcaniclastics and quartzphyllites.

As a matter of fact, the slopes and the road-way deterioration range from the visual impact to the complete blockade or even the induced failure of the road-way structure (SOBRINHO, 1988; ZIKA, 1990; BASKERVILLE et al., 1993). It is here made an attempt to check the index of Rock Deterioration Assessment (RDA), which is here also evaluated with a slightly modified configuration, against the Actual Deterioration of the Slopes (ADS). In fact, it was possible to assess this deterioration ten years after the road cutting. The assessed indices can be obtained strictly on the basis of the visual characterisation of the slopes.

\section{GEOLOGICAL SETTING AND THE COLLECTED DATA}

The terrains herein envisaged, which belong specifically to the denominated Lower Allochtonous Thrust Complex (LATC) of the Galiza - Trás-os-Montes Zone (GTMZ), are composed of two lithologic suites; the Lower Unit is essentially made of micaschists and the Upper Unit comprehends metamorphic rocks after a volcano-sedimentary sequence and its prograded acidic, intermediate and basic submarine flows and volcaniclastics (SÁ et al., 2000a).

Upwards the LATC it is found the Ophiolitic Thrust Complex (OTC), with relevant affinities to the LATC. Here, from top to bottom, it can be seen the following sequence: greenstones (amphibolites), sheeted dyke complex of greenstones (amphibolites), flaser gabbros, melagabbros and serpentinized lherzolites (RIBEIRO et al., 1990).

As these highway slopes were excavated in early 1990's and the Rockslope Deterioration Assessment (RDA) was estimated in 1998, it was considered the need to assess the actual deterioration with a campaign of field work focused on the sites with previously determined values of RDA following NICHOLSON \& HENCHER (1997). So, four parameters were considered (SÁ et al., 2000b) and adequately dimensioned:

a) the average spacing of the discontinuities;

b) the average openings of the discontinuities;

c) the strength of the rock mass;

d) the degree of weathering.

For this particular case study, due to its rather anisotropic rock fabric, a fifth parameter was considered:

e) the dihedral angle between the "slope plane" and the major discontinuity(ies) of the rock mass (Table 1). 
Table 1 - Factors corresponding to the dihedral angle $\left(5^{\text {th }}\right.$ parameter $)$ between the slope plane and the major discontinuities of the rock mass.

\begin{tabular}{c|c}
\hline & Value \\
\hline$>50^{\circ}$ & 1 \\
\hline $40^{\circ}-50^{\circ}$ & 3 \\
\hline $20^{\circ}-40^{\circ}$ & 8 \\
\hline $10^{\circ}-20^{\circ}$ & 15 \\
\hline$<10^{\circ}$ & 25 \\
\hline
\end{tabular}

Table 2 - Susceptibility classes using RDA method vs. Susceptibility classes using RDA method and the $5^{\text {th }}$ parameter (SÁ et al., 2000b).

\begin{tabular}{|c|c|c|c|c|c|}
\hline Site & $\Sigma$ RDA & RDA Classes & $5^{\text {th }}$ parameter & $\Sigma \mathrm{RDA}+\mathrm{e}$ & Final Class \\
\hline 2 & 64 & 4 & 8 & 72 & 4 \\
\hline $2 \mathrm{~A}$ & 70 & 4 & 3 & 73 & 4 \\
\hline 3 & 66 & 4 & 1 & 67 & 4 \\
\hline $3 \mathrm{~A}$ & 61 & 4 & 8 & 69 & 4 \\
\hline 8 & 53 & 3 & 1 & 54 & 3 \\
\hline 13 & 67 & 4 & 8 & 75 & 4 \\
\hline $13 \mathrm{~A}$ & 66 & 4 & 15 & 81 & 5 \\
\hline 14 & 67 & 4 & 8 & 75 & 4 \\
\hline 17 & 69 & 4 & 3 & 72 & 4 \\
\hline 18 & 82 & 5 & 1 & 83 & 5 \\
\hline 19 & 83 & 5 & 3 & 86 & 5 \\
\hline $19 \mathrm{~A}$ & 90 & 5 & 8 & 98 & 5 \\
\hline 20 & 78 & 4 & 8 & 86 & 5 \\
\hline $20 \mathrm{~A}$ & 85 & 5 & 1 & 86 & 5 \\
\hline 21 & 84 & 5 & 15 & 99 & 5 \\
\hline 25 & 77 & 4 & 8 & 78 & 4 \\
\hline $25 \mathrm{~A}$ & 66 & 4 & 3 & 69 & 4 \\
\hline $25 \mathrm{~B}$ & 75 & 4 & 3 & 78 & 4 \\
\hline 26 & 65 & 4 & 1 & 66 & 4 \\
\hline 27 & 65 & 4 & 3 & 68 & 4 \\
\hline 29 & 62 & 4 & 8 & 70 & 4 \\
\hline 34 & 75 & 4 & 3 & 78 & 4 \\
\hline 39 & 79 & 4 & 1 & 80 & 5 \\
\hline 46 & 63 & 4 & 3 & 66 & 4 \\
\hline
\end{tabular}

The existence of discrete faults, as well as the technology used to make the road cut, and the height and tilt of the slopes are also used to compute the weighted sum that stands for the susceptibility index. Herein the deterioration susceptibilities fit within the interval 54 to 99 (the full interval ranges from 6 to 160). 
The ADS index, which considers the factors (see Table 3):

a) type of deterioration (rock fall, landslide, toppling and creep);

b) length of the deteriorated slope;

c) volume of the slided rock material;

d) dimension (estimated weight) of the major blocks.

All these factors can be evaluated and classified very quickly during the field surveying and should be photographically recorded in order to make possible the relative analysis of the series of sites. This relative evaluation is necessary if the surveying is discontinuous and performed by several operators.

Table 3 - Indices of Actual Deterioration of Slopes (ADS), Rock deterioration Assessment (RDA) and transformed RDA (RDA+e). Legend for the factors of ADS. Type - Rock fall=4; Landslide $=3$; Toppling $=2$; Creep $=1$; the second factor counts with $50 \%$; Length $-<5 \mathrm{~m}=1 ; 5-10 \mathrm{~m}=2 ;>10 \mathrm{~m}=3$; Volume - considering the length of 25 meters, $<1 \mathrm{~m}^{3}=1 ; 1-5 \mathrm{~m}^{3}=2 ; 5-10 \mathrm{~m}^{3}=3 ; 10-100 \mathrm{~m}^{3}=4$; $100-500 \mathrm{~m}^{3}=5$; Major block weight $-<20 \mathrm{~kg}=1 ; 20-50 \mathrm{~kg}=2 ; 50-100 \mathrm{~kg}=3 ;>100 \mathrm{~kg}=4$.

\begin{tabular}{c|c|c|c|c|c|c|c}
\hline Site n. & Type & Length & Volume & Block dim. & ADS & RDA & RDA+e \\
\hline 2 & 4 & 2 & 4 & 3 & 13 & 64 & 72 \\
\hline $2 \mathrm{~A}$ & 4 & 1 & 2 & 1 & 8 & 70 & 73 \\
\hline 3 & 5 & 3 & 4 & 2 & 14 & 66 & 67 \\
\hline $3 \mathrm{~A}$ & 5 & 3 & 4 & 1 & 13 & 61 & 69 \\
\hline 8 & 4 & 1 & 2 & 3 & 10 & 53 & 54 \\
\hline 13 & 4 & 3 & 2 & 1 & 10 & 67 & 75 \\
\hline $13 \mathrm{~A}$ & 4 & 3 & 2 & 1 & 10 & 66 & 81 \\
\hline 14 & 4 & 1 & 2 & 2 & 9 & 67 & 75 \\
\hline 17 & 5 & 2 & 3 & 3 & 13 & 69 & 72 \\
\hline 18 & 5 & 3 & 4 & 2 & 14 & 82 & 83 \\
\hline 19 & 6 & 3 & 5 & 4 & 17 & 83 & 86 \\
\hline $19 \mathrm{~A}$ & 6 & 3 & 5 & 4 & 19 & 90 & 98 \\
\hline 20 & 6 & 3 & 5 & 4 & 18 & 78 & 87 \\
\hline $20 \mathrm{~A}$ & 6 & 3 & 5 & 4 & 18 & 85 & 86 \\
\hline 21 & 5 & 3 & 5 & 3 & 16 & 84 & 99 \\
\hline 25 & 5 & 3 & 4 & 3 & 15 & 77 & 78 \\
\hline $25 \mathrm{~A}$ & 5 & 3 & 4 & 2 & 14 & 66 & 69 \\
\hline $25 \mathrm{~B}$ & 5 & 3 & 4 & 3 & 15 & 75 & 78 \\
\hline 26 & 5 & 3 & 4 & 3 & 15 & 65 & 66 \\
\hline 27 & 1 & 2 & 4 & 2 & 9 & 65 & 68 \\
\hline 29 & 1 & 2 & 4 & 3 & 10 & 62 & 70 \\
\hline 34 & 6 & 3 & 5 & 3 & 17 & 75 & 78 \\
\hline 39 & 5 & 3 & 6 & 3 & 17 & 79 & 80 \\
\hline 45 & 1 & 3 & 3 & 3 & 10 & 63 & 66 \\
\hline & & & & & & &
\end{tabular}


If the RDA is modified to include the parameter e) which emphasises the role that the major joints or foliations play in the cases of rock fall and in some cases of landslides, the transformed RDA (RDA+e) shifts to higher values. The classes that were used for the new index have been maintained as they are used when the parameter is the classical RDA. In this case study only three sites (13A, 20 and 39) ought to be considered as shifted from the $4^{\text {th }}$ to the $5^{\text {th }}$ classes. There are clearly sites where the deteriorated type is in the group of the rock fall.

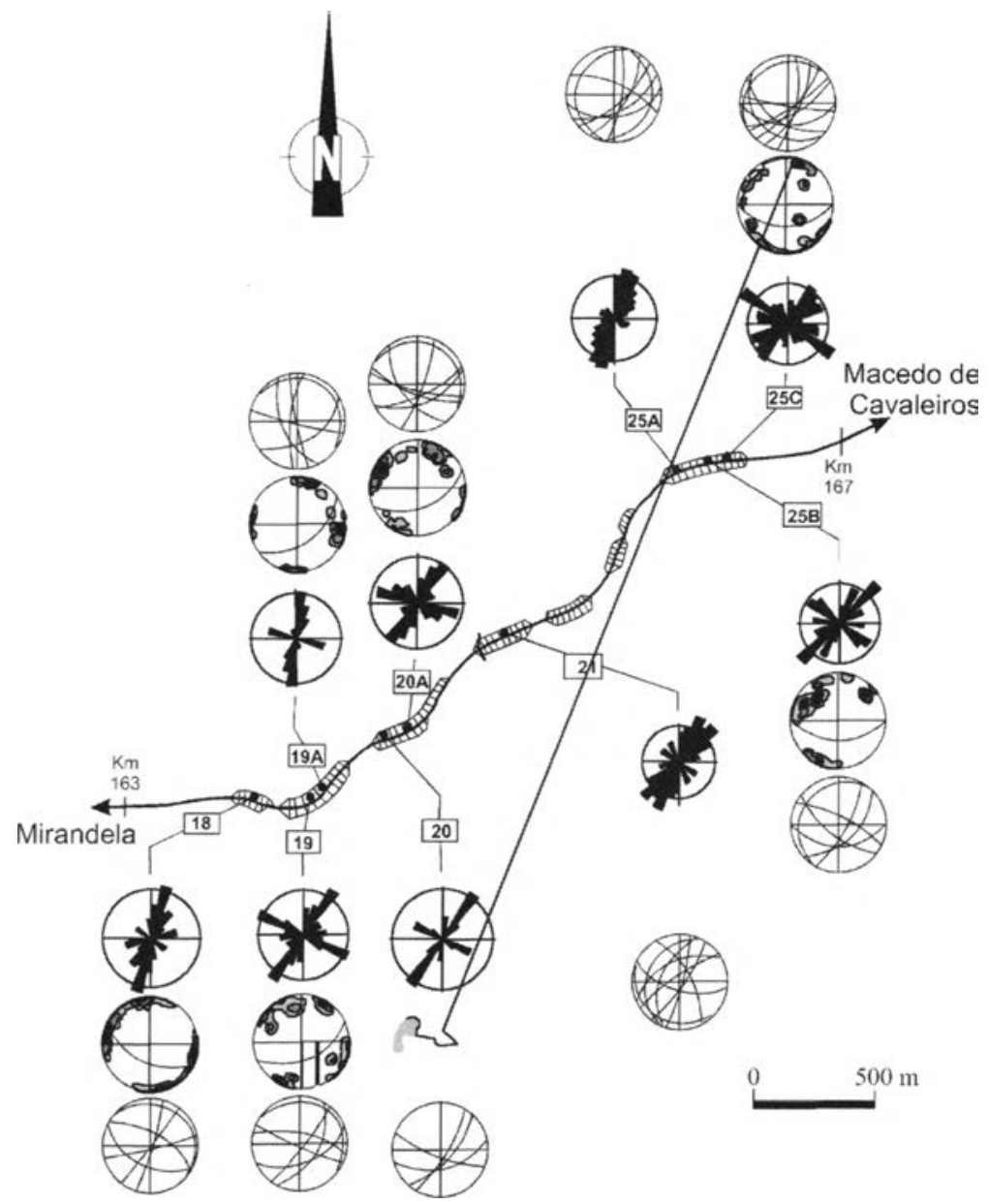

Fig. 1 - Segment of the highway between sites 18 and 25. The set of three stereograms made for each side shows a) density of the joint families; b) the density of joint plus the attitude of slope and c) attitude of major families of discontinuities (adap. SÁ, 1999). 
In fact, it could have been an attempt to emphasise the role of the pair of the discontinuities that are more influential for the movement of the rock material.

It was expected that the reformulated RDA as RDA+e would give a better picture of the potential deterioration of the slopes.

The sites where the deterioration has been more active (consequently the RDA and ADS have the higher values - Tables 1,2 and 3) have been telescoped from the overall map with the discontinuities (Fig. 1).

In this map are shown all the geometric features that should be considered in the processes of mechanical degradation of the rock slopes namely the azimuth and the dip of the slope, the major foliation of the metamorphic rocks, the geometry of the families of joints. The stereograms might be used to propose which are the joint sets potentially active, namely to induce the sliding of blocks controlled joints that make dihedra openly plunging to the slope.

\section{CONClusions}

The surveying of the IP4 highway slopes along a stretch of $20 \mathrm{~km}$ was intended for its detailed geological and geotechnical analysis, namely for the diagnosis of their instability. This survey gives a sound picture of the discrete sections with sizeable potential of risk. The risks are to be assigned to multiple classes, degrees of instabilities, and mechanisms of deterioration.

The evaluation of the susceptibility for deterioration and the also the assessment of the actual deterioration have been made with very simple techniques and with the minimum equipment. The cost of a study like this is to be taken into account. Furthermore, the factors used to evaluate the Rockslope Deterioration Assessment (RDA) rely on the observation that fairly trained geologist or engineer is qualified to carry on.

It is clearly emphasised that the mechanisms of deterioration and the grading of instability are strongly dependent from the geometry of the slope and from lithological and tectonic parameters. So, the expert geological identification and the forecasting of the behaviour, consequent to the petrographic, structural and weathering parameters, ought to be taken into account for the construction and maintenance of the road slopes - techniques and costs. They help to choose the geometry of the slope as well as their monitoring devices, the drainage and sustenance systems and the remediation techniques.

The evaluation of the deterioration susceptibilities of the highway slopes was made using the method RDA modified with a factor relative to the dihedral angle between the "slope plane" and the major discontinuity(ies) of the rock mass.

This geotechnical survey, which was made ten years after the highway construction, adds a good amount of information to the pre-construction surveying and to the forecast made five years after the road opening. 
It is made clear that the most serious situations of deterioration occur in the high way slopes escavated in the volcano-sedimentary rock units (quartzphillites with interlayered metarhyolites, namely where they show sulphides of exalative parentage), and also where the attitude of the mesoscopic tectonic structures is adequately oriented to maximize the deterioration mechanisms.

It is also clear that the southern slopes of the highway were properly shaped with steeper dips and without the "stairs" that appear to have been "carved" as a "mirror" image of those carved on the northern slopes, where they are really necessary.

a)
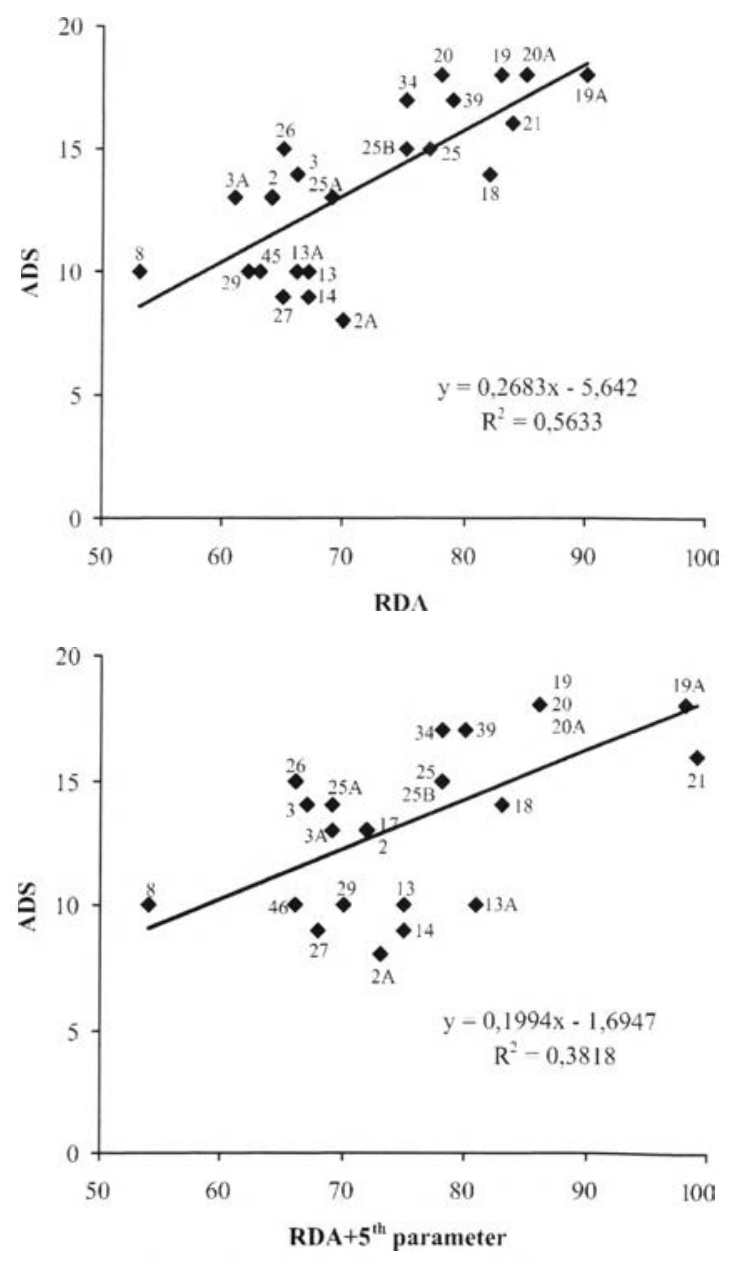

Fig. 2 - Correlation between a) on the top the index of Rockslope Deterioration Assessment (RDA) and the index of Actual Deterioration of the Slopes (ADS) and b) on the bottom the modified index of Rockslope Deterioration Assessment (RDA+e) and the index of Actual Deterioration of the Slopes (ADS). 
If the pre-construction detailed and expert geological-geotechnical surveying is apt to optimize the road project, as well as its construction and maintenance, the prograding of the deterioration can be minimized if the new findings are incorporated in the "remediation prescription". This is much so as one takes into consideration the assessment of the parameters visualized on the rock materials detached from the slopes after the first decade of the slopes life.

In fact, it is here shown that the prospected vulnerability evaluated on the basis of the morphology of the slope, rock types, weathering degrees and the mechanical discontinuities of the rock units is positively correlated with the dimensioned rock masses detached from the highway slopes $\left(\mathrm{ADS}=0,26 \mathrm{RDA}-5,64\right.$ for an $\left.\mathrm{R}^{2}=0,56\right)$ (Fig. 2).

\section{REFERENCES}

Baskerville, C. A.; Lee, F.T. \& Ratté, C. A. 1993. Landslide Hazards in Vermont. U.S. Geological Survey Bulletin 2043, USGS, Denver. 23p.

Betran-Moreno, L. 1990. Characteristics of the mass movements in road slopes in Colombia. 6th Int. IAEG Congress, Balkema, Rotterdam, IV: 2093-2098.

Gonzalez del Vallejo, L. I.; Ferrer, M.; Ortuño, L. \& Oteo, L. 2002. Ingeniería Geológica. Cap. 9: Taludes, pp. 430-487. Pearson Educación, Madrid.

Koukis, G.; Tsiambaos, G. \& SabataKaKis, N. 1997. Landslide movements in Greece: Engineering geological characteristics. In Marinos, Koukis, Tsiambaos \& Stourmaras (eds). Engineering Geology and the Environment: Balkema, Rotterdam, II: 789-792.

Nicholson, D. T. \& HenCher, S. 1997. Assessing the potencial for deterioration of engineered rockslopes. In Marinos, Koukis, Tsiambaos \& Stourmaras (eds). Engineering Geology and the Environment,. Balkema, Rotterdam, II: 911-917.

Ouiveira, R. 1979. Taludes naturais e de escavação. Universidade Nova de Lisboa, Lisboa. 23p.

Perry, J. \& O'Reilly, M. P. O. 1990. A survey of slope condition on British motorways. 6th Int. IAEG Congress, Balkema, Rotterdam, IV: 2271-2278.

Ribeiro, A.; Pereira, E. \& Dias, R. 1990. Alloctonous Sequences. In Dallmeyer, R.D. \& Martinez Garcia, E. (Eds). Pre-Mesozoic Geology of Iberia, Springer Verlag, Berlim: 220-236.

SÁ, A. A. 1999. Deterioração e requalificação de taludes em unidades tipificadas de metavulcanitos e metassedimentos (Mirandela-Macedo de Cavaleiros, NE Portugal). MSc. Thesis, unpubl., FCTUC, Universidade de Coimbra, Coimbra. $241 \mathrm{p}$.

SÁ, A.A., Pires, C.A.C. \& Portugal. Ferreira, M.R. 2000a. Refined lithostratigraphy from the Lower Allochtonous Unit westwards of the Morais Massif (NE Portugal). In: VariscanAppalachian dynamics: the building of the Upper Paleozoic basement. Basement Tectonics 15, A Coruña, Spain, Program and Abstracts: 275-277.

SÁ, A.A.; Pires, C.A.C. \& Portugal Ferreira, M.R. 2000b Deterioration and Remediation of Higway Slopes on Ophiolitic Rocks: case study on NE Portugal. $3 I^{s t}$ International Geological Congress, Rio de Janeiro, Brazil. CD-Rom Abstracts.

SoBRINHO, R. R. S. 1988. Uma abordagem em direç̧ão à previsão de movimentos de massa - o caso da Rio-Santos (Trecho Itaguaí-Conceição de Jacareí). Geociências 7, São Paulo: 43-76.

YINGQING, Z. 1994. A expert system for the prediction of slope stability. 7th Int. LAEG Congress Lisboa, Balkema, Rotterdam, V: 4483-4488.

ZIKA, P. 1990. Engineering-geological evaluation of the rock cuts stability along the D1 highway. 6th Int. IAEG Congress, Balkema, Rotterdam, IV: 2423-2427. 